Paedagogia Christiana

2/30 (2012) - ISSN 1505-6872

Andrzej Potocki*

Warszawa

\title{
Polska młodzież w obszarze badawczych zainteresowań ks. Janusza Mariańskiego
}

Nasza młodzież to, przyznajmy, nader atrakcyjny obiekt badań; zwłaszcza jeśli chcemy ją oglądać w kontekście wielokierunkowych - a charakterystycznych dla ostatnich dziesiątek lat - procesów modernizacyjnych. Zresztą pewnie nie wypada oglądać jej inaczej. Kilkadziesiąt minionych lat to czas ścierania się wyraźnie zdystansowanych wobec siebie nurtów idei moralnych. Najpierw był to czas ścierania się nurtu moralności katolickiej i moralności socjalistycznej, potem nurtu moralności katolickiej i moralności liberalnej. Trudno zaprzeczyć, że wszystkie te nurty poprzez właściwe sobie - a występujące mniej bądź bardziej jawnie - formy instytucjonalizacji były i są zainteresowane pozyskiwaniem dla swych propozycji młodego pokolenia. Czy i na ile działania w tym zakresie były i są skuteczne? Oto pytanie dla socjologa. Takim jest ks. prof. J. Mariański, aktualnie kierownik Katedry Socjologii Moralności w Instytucie Socjologii KUL-u, uznany autorytet $\mathrm{w}$ dziedzinie socjologii religii, socjologii moralności, socjologii młodzieży. Niedawny jubileusz 70-lecia urodzin zachęca do podjęcia próby syntetycznego oglądu jego dorobku. Zważywszy charakter naszego półrocznika, zatrzymamy się przy zainteresowaniach J. Mariańskiego problematyką młodzieży, zwłaszcza światem jej wartości kształtowanym wielorakimi wpływami wychowawczymi pluralizującego się społeczeństwa. Mówi się

* Prof. dr hab. Andrzej Potocki OP - teolog i socjolog; profesor w Instytucie Profilaktyki Społecznej i Resocjalizacji Uniwersytetu Warszawskiego, w Instytucie Filozofii i Socjologii Akademii Pedagogiki Specjalnej im. M. Grzegorzewskiej w Warszawie, w Kolegium Filozoficzno-Teologicznym oo. Dominikanów w Krakowie. 
o niektórych ludziach, że wygrali los na loterii. Wiele wskazuje na to, że należy do nich także ks. Janusz Mariański; przynajmniej w swej roli badacza młodzieży. Bo lata jego naukowej twórczości przypadły na czasy niebywale atrakcyjne poznawczo.

\section{Zaczyna się w Plocku}

Dziś ważne dla naszego autora jest przyglądanie się polskiej młodzieży na tle jej uwikłań w kulturę zwaną ponowoczesną. Biorąc to, co wyżej, pod uwagę, nie może nas dziwić, że swoje badania młodzieży sytuuje J. Mariański w szeroko zakrojonym, wielowymiarowym kontekście społecznym. Po prostu, o ile chce być - a przecież chce i faktycznie jest - badaczem rzetelnym, inaczej nie może. Co więcej, charakter tego kontekstu czynić musi badacza wrażliwym na fenomen zmiany społecznej; konstytutywny w warunkach tak wyrazistej modernizacji społecznej, jak ta, która od ponad dwóch dekad stała się naszym udziałem.

Zmienność czasu, zwłaszcza politycznego czasu, rzutuje na dobór tematów badawczych, ale i definiuje organizacyjne uwarunkowania badań. Ciekawe jest to obserwowanie korelacji programów badawczych i sposobów ich realizacji z modelem organizacyjnym polskiej socjologii: z jej możliwościami i ograniczeniami. Pierwsza większa praca ks. J. Mariańskiego o naszej młodzieży to książka Postawy spoleczno-moralne młodzieży płockiej (studium socjologiczne)1. Przynosi plon badań autora w Płocku w 1981 roku. Rzecz przygotowana w ramach badań prowadzonych przez Komitet Badań Rejonów Uprzemysławianych PAN. Stąd problematyka młodzieży dostaje korelat: proces industrializacji. Korelat w istocie tradycyjny, obecny w polskiej socjologii także we wcześniejszych dekadach. Ks. J. Mariański bada młodzież uczącą się w różnych typach ówczesnych szkół ponadpodstawowych i na Politechnice. Przygotowuje studium o charakterze diagnostyczno-eksplikatywnym. Za spisem treści łatwo wymienić zagadnienia: stosunek młodzieży do moralności, rygoryzm i relatywizm moralny, postawy prospołeczne i egoistyczne, hierarchia wartości codziennych i uroczystych, godność ludzka jako wartość społeczna, stosunek młodzieży do wybranych norm moralnych: stosunek do normy miłości bliźniego, postawy wobec prawdomówności i kłamstwa, postawy wobec własności prywatnej i społecznej, dalej sprawa autorytetów w dziedzinie moralności. Wybrane wątki tych badań autor pokazuje na łamach jednego z czasopism naukowych KUL, „Rocznika Nauk Społecznych” (Wspótzależność postaw zasadniczo-celowo-

\footnotetext{
1 Płock 1984.
} 
ściowych i godnościowych [na przykładzie młodzieży uczqcej się w Płocku]²; Postawy zasadnicze i celowościowe a wartości uznawane przez młodzież. Na przykładzie młodzieży uczqcej się w Płockuß; Teraźniejszość i przyszłość. Stosunki międzyludzkie w opinii młodzieży ${ }^{4}$ ). Gdzie indziej pokazuje Orientacje zasadnicze i celowościowe jako czynnik różnicujacy postawy prospoteczne młodzieży plockiej. ${ }^{5}$. Preferowanie wspomnianych orientacji koreluje tu z globalną postawą prospołeczną, z zaufaniem do ludzi, z gotowością niesienia im pomocy, z motywami działań prospołecznych. Co z tych badań wynikało, pozostawiamy na boku. Bo nie referowanie wyników jest celem tego przedłożenia. Jednakże same tematy warto wyeksponować. One określą przestrzeń zainteresowań badawczych autora na długie lata. I dobrze. Będzie szansa na kompetentnie formułowane wnioski. Już w tej „płockiej” książce zasygnalizuje Mariański sobie właściwy sposób prezentacji własnych wyników: na tle i w zestawieniu porównawczym z wynikami innych polskich badań nad młodzieżą.

\section{O sensie życia i wartościach młodzieży}

Jeszcze w latach 80. ukazuje się ważny tekst ks. J. Mariańskiego stanowiący poniekąd zapowiedź tematu, który potem na długo zagości na stole pracy naszego badacza. To Sens życia w świadomości młodzieży szkót średnich ${ }^{6}$. Podstawę empiryczną dla tych rozważań dają trzy badania socjologiczne zrealizowane w latach 1984-85 na próbie młodzieży szkół średnich ze Skarżyska-Kamiennej, Sierpca i Zduńskiej Woli. Przyglądamy się opiniom młodzieży na temat sensu życia (osobom, z którymi o sensie życia młodzież rozmawia, czynnikom kształtującym poglądy młodzieży na temat sensu życia), aksjologicznej perspektywie sensu życia, związkom między poglądami na sens życia i poziomem religijności.

W okresie PRL-u i w warunkach ówczesnego modelu organizacji badań socjologicznych znalazły się ponadto badania robione na przełomie 1988/89 roku w ramach programu CPBP 08.18 Świadomość polityczna młodzieży oraz jej uwarunkowania koordynowanego przez Instytut Badań Problemów Młodzieży. Ich efektem stała się praca zbiorowa pod redakcją J. Mariań-

2 „Roczniki Nauk Społecznych” 1 (1985), s. 107-141.

3 „Roczniki Nauk Społecznych” 1 (1986), s. 125-158.

4 „Roczniki Nauk Społecznych” 1 (1987), s. 95-124.

5 „Notatki Płockie. Kwartalnik Towarzystwa Naukowego Płockiego” 4 (1989), s. $39-48$.

6 „Seminare. Poszukiwania Naukowo-Pastoralne” (1986), s. 99-140. 
skiego i W. Zdaniewicza Wartości religijne i moralne młodych Polaków (raport z badań ogólnopolskich)7. Badano uczniów szkół ponadpodstawowych i uczniów szkół policealnych z 83 szkół w 18 miejscowościach oraz studentów z 40 wydziałów uczelni z 15 miast. Ankieta dotyczyła wartości ostatecznych, podstawowych i codziennych, choć pomieszczona przez naszego autora relacja z badań zatrzymała się na wartościach religijnych i moralnych. J. Mariański opisuje wartości życiowe ogólne i konkretne, prospołeczne i egoistyczne, ascetyczne i samorealizacyjne oraz egzystencjalne.

Wyniki tych samych badań posłużyły mu jednocześnie do przygotowania książki Kondycja religijna i moralna młodych Polaków ${ }^{8}$. Zastanawia adnotacja pomieszczona przez wydawcę na frontispisie: „Praca została przygotowana w ramach Centralnego Programu Badawczego pt. Systemy wartości wyznań i grup wyznaniowych w Polsce koordynowanego przez Instytut Religioznawstwa UJ". Wolno domniemywać - by jakoś wyjść z tej niejasnej sytuacji - że badania były koordynowane przez Instytut Badań Problemów Młodzieży, choć faktycznie prowadzone pod egidą Instytutu Religioznawstwa. Jednak takie wyjaśnienie, aczkolwiek zapewne słuszne, nie okazuje się wystarczające, bowiem na stronie 10 dociekliwy czytelnik (ach, po co on jest tak dociekliwy) dowie się, że badania zrealizowano „na zlecenie Instytutu Badań Problemów Młodzieży przez Zakład Socjologii Religii Stowarzyszenia Apostolstwa Katolickiego w Warszawie. Koordynatorami badań byli: Janusz Mariański, Władysław Piwowarski i Witold Zdaniewicz". Koordynatorami - to już trzeci poziom koordynacji. A kto to faktycznie robił? Pewnie kol. Janusz Mariański osobiście. Niżej podpisany piewca dorobku niedawnego Jubilata zatrzymał się na tej sui generis ciekawostce, bo chce - i pewnie może - potraktować ją jako dobrą ilustrację niegdysiejszych klimatów organizowania badań socjologicznych. Tak wypadało robić, o ile chciało się wyraźniej wykroczyć poza warsztat badań empirycznych wyznaczonych technicznymi możliwościami badań autorów prac magisterskich i doktorskich. I tak w istocie - przypuszcza autor niniejszego - kamuflowano socjologiczną działalność pallotynów, ukrywając ich pod zasłonką Uniwersytetu Jagiellońskiego przed wzrokiem płk. Jana Bogusza dyrektorującego wówczas w Instytucie Badań Problemów Młodzieży na ul. Zagórnej w Warszawie. W tej książce - jeszcze niezbyt grubej (112 stron), zatem pochodzącej z okresu „młodego Mariańskiego” - znajdujemy charakterystykę, jak zapowiada tytuł, kondycji religijnej i kondycji moralnej młodzieży. W kontekście powiązania wskazanych tu badań z Uniwersytetem Jagiellońskim nie dziwi pojawienie się kolejnej publikacji J. Mariańskiego w fundamentalnym cza-

\footnotetext{
7 Warszawa 1991.

${ }^{8}$ Kraków 1991.
} 
sopiśmie UJ. Chodzi o artykuł Kondycja religijna młodych Polaków '889. Po wprowadzeniu w problematykę autor pokazuje globalne postawy wobec religii, postawy badanej młodzieży wobec dogmatów katolickich, parametr doświadczenia religijnego, uczestnictwo młodzieży w praktykach religijnych, jej stosunek do norm moralnych. W tym samym klimacie utrzymuje się tekst Religijność młodzieży polskiej z końca lat 80-tych ${ }^{10}$. Także tutaj staja globalne postawy wobec religii, dalej poziom wiary w dogmaty, postawy młodzieży wobec chrześcijańskiej moralności małżeńsko-rodzinnej, poziom rygoryzmu moralnego, zaangażowanie młodego pokolenia w praktyki religijne.

\section{Postawy i zachowania moralne}

Tymczasem mocno się uwyraźnia perspektywa poznawcza, która już na stałe określi warsztat pracy naszego autora. Jest nią ogląd postaw i zachowań moralnych młodego pokolenia w powiązaniu z poziomem i charakterem jego religijności. Tak spotka się J. Mariański socjolog młodzieży i J. Mariański socjolog religii. Spotka się już na stałe (Moralność religijna młodych Polaków w nowoczesnym społeczeństwie ${ }^{11}$ ). Wiemy, że wśród polskich badań dotyczących poziomu i charakteru religijności różnych kategorii społecznych i zawodowych analizy dotyczące religijności młodzieży należą z pewnością do najlepiej rozwiniętych i - w efekcie - najbogatszych w wyniki i wnioski. I to w znacznej mierze dzięki ks. J. Mariańskiemu.

Przyszły nowe czasy. Janusza Mariańskiego, badacza młodzieży, nie pozostawiły obojętnym. Obserwuje i chce pokazać cele i dążenia, zatem wartości życiowe polskiej młodzieży w pierwszym etapie przechodzenia od tak zwanego realnego socjalizmu do społeczeństwa demokratycznego o orientacji rynkowej. Pyta, które to wartości najwyraźniej określają orientację życiową i społeczne funkcjonowanie młodego pokolenia. Wykorzystuje wyniki badań zrealizowanych w latach 1989-90 przez Zakład Socjologii Religii pallotynów i Zakład Socjologii Religii KUL wśród młodzieży szkół ponadpodstawowych, młodzieży pracującej i żołnierzy pełniących zasadniczą służbę wojskową. Zestawia z wynikami przywoływanych już badań koordynowanych przez Instytut Badań Problemów Młodzieży. Efektem jest

9 „Zeszyty Naukowe Uniwersytetu Jagiellońskiego. Studia Religiologica” 25 (1992), s. $83-103$.

10 „Universitas Gedanensis” 4 (1990).

11 „Roczniki Nauk Społecznych” 1 (1993), s. 137-154. 
rozprawa Cele i dażenia życiowe młodzieży polskiej w latach 1989-199012. Identyfikuje tu preferencje respondentów w zakresie bliskich im wartości życiowych i określa wartości nadające życiu sens. Zbliżoną bazę materiałów empirycznych wykorzystuje J. Mariański niedługo potem, przygotowując tekst Młodzież wspótczesna wobec wartości $i^{13}$. Odnosi się w nim do postrzegania przez młodzież wartości codziennych, wartości „uroczystych” oraz wartości związanych z małżeństwem i rodzina.

Powtórzmy: przyszły nowe czasy. Niegdysiejsze, wyznaczane przez aparat polityczny centralne programy badawcze przechodzą do historii. J. Mariański szuka nowego sposobu na badania. I znajduje. Oto konstruuje swe publikacje w formie poważnych syntez wyników badań swoich uczniów: doktorantów, magistrantów. Ci ostatni znajdują szansę na promocję swych w istocie raczej wąsko zakrojonych badań, Mariański - umiejętnie kierując pracami podopiecznych, a zwłaszcza starannie, planowo je koordynując znajduje szansę na dopływ pożytecznego dlań materiału empirycznego. Wyraźnie zabiega o komplementarność prowadzonych badań monograficznych. Bo na horyzoncie swej badawczej wyobraźni ma już ich syntezę. Pewnie od razu wiele syntez.

I tak w artykule Postawy młodzieży polskiej wobec sensu życia ${ }^{14}$ wprawdzie opublikowanym dopiero po kilku latach, daje prezentację wyników wielu badań cząstkowych zrealizowanych w latach 1989-93 w ramach prac magisterskich w Katedrze Socjologii Religii KUL. Uwzględnia też badania w Katedrze Socjologii Moralności tej uczelni. Dla celów porównawczych także inne badania. Pokazuje częstotliwość myślenia młodych ludzi o celu i sensie życia, zadowolenie z życia i przekonanie o jego sensie, także poczucie bezsensu życia. Problematyka sensu życia doświadczanego przez młode pokolenie została już wcześniej pokazana poprzez zestawienie wyników uzyskanych dzięki badaniom zrobionym na zlecenie Instytutu Badań Problemów Młodzieży $\mathrm{z}$ badaniami zrealizowanymi $\mathrm{w}$ wybranych środowiskach młodzieży szkolnej w Warszawie, Łukowie i Łochowie (przez pallotyński Zakład Socjologii Religii) oraz w Pionkach (przez Zakład Socjologii Religii KUL). To u schyłku lat 80. Efektem był artykuł Religijność a postawy młodzieży wobec sensu życia ${ }^{15}$. Widać tu opinie młodzieży o religijnym i pozareligijnym sensie życia, powiązanie myślenia o sensie życia i śmierci z poziomem religijności, powiązanie religijności z poczuciem sensu i bezsensu

12 „Roczniki Teologiczne” 6 (1991-1992), s. 117-132.

13 „Roczniki Teologiczne” 6 (1994), s. 135-159.

${ }^{14}$ w: K. Popielski (red.), Człowiek - wartości - sens. Studia z psychologii egzystencji. Logoteoria i nooteoria. Logoterapia i nooterapia, Lublin 1996, s. 289-307.

15 „Summarium” 19 (1990), s. 5-23. 
życia. Wątki te wracają po latach w artykule Postawy młodzieży wobec sensu $\dot{z y c i a}{ }^{16}$. Także w Sens i bezsens życia $w$ doświadczeniach młodzieży polskiej ${ }^{17}$. A zwłaszcza w publikacji książkowej Między nadzieja i zwatpieniem. Sens życia w świadomości młodzieży szkolnej ${ }^{18}$. Daje tu nasz autor syntezę wyników badań zrealizowanych w szkołach średnich, w ich pierwszych i w ostatnich klasach, w latach 1994-96 w ośmiu wybranych miastach w różnych regionach kraju. Są tu Radom, Jędrzejów, Płock, Gdańsk, Szczecinek, Warszawa, Starogard i Chełm. W przypadku każdego miasta mamy do czynienia z celowo-losowym doborem próby. Dostajemy opis postaw młodzieży wobec sensu życia, przy czym duże znaczenie ma dla autora pytanie o religię jako instancję sensotwórczą. Ważne dla ks. J. Mariańskiego są tu cele i dążenia życiowe młodzieży, jej wartości codzienne, poczucie sensu i bezsensu życia. Na tym samym materiale empirycznym opiera się Mariański, pokazując i komentując myślenie młodzieży o przyszłości (Przyszłość własna i spoteczeństwa $w$ opinii młodzieży $\left.{ }^{19}\right)$. Omawia zadowolenie młodych respondentów z życia oraz ich opinie o przyszłości osobistej i przyszłości własnego kraju. Przyszłość dalej idąca dochodzi do głosu w artykule także opartym na materiale badawczym zgromadzonym w ośmiu wspomnianych miastach, a mianowicie Postawy młodzieży szkolnej wobec spraw ostatecznych ${ }^{20}$. Tekst poświęcony jest postawom młodzieży wobec umierania i śmierci oraz chrześcijańskiej eschatologii. Uzyskane wyniki prezentowane są w przekroju kilku cech społeczno-demograficznych i dwóch cech religijnych (postawy wobec religii, poziom praktyk religijnych). Na tle tego dorobku za ciekawostkę uznać wolno artykuł Postawy młodzieży austriackiej $i$ zachodnioniemieckiej wobec sensu życia (refleksje socjologiczno-pastoralne) ${ }^{21}$. Rozumiemy, że jest tu prezentacja wyników odnośnych badań socjologicznych w obu krajach.

\section{Badania maturzystów}

Od strony metody badań analogiczną procedurę - jak w polskich badaniach postaw młodzieży wobec sensu życia - odnajdujemy w przypadku badań maturzystów, zrealizowanych w 1994 roku w sześciu miastach. To Dę-

16 „Zeszyty Naukowe Wyższej Szkoły Menedżerskiej Stowarzyszenia Inicjatyw Gospodarczych" 1 (1997), s. 181-203.

17 „Roczniki Nauk Społecznych” 1 (1999), s. 119-146.

${ }^{18}$ Lublin 1998.

19 „Universitas Gedanensis” 1-2 (1999), s. 129-141.

${ }^{20}$ w: L. Adamczuk i in. (red.), Kościót. Socjologia. Statystyka. Księga jubileuszowa poświęcona księdzu profesorowi Witoldowi Zdaniewiczowi SAC, Warszawa 1999, s. 136-150.

${ }^{21}$ „Zeszyty Naukowe KUL” 3-4 (1986), s. 95-114. 
blin, Gdańsk, Kraśnik, Puławy, Szprotawa i Tarnów. Choć te ośrodki miejskie mają zróżnicowany charakter, to trudno tu oczywiście mówić o jakiejkolwiek reprezentatywności. J. Mariański czuwa nad tym ograniczeniem. Ów projekt badań znajduje niebawem przełożenie na książkę Młodzież między tradycja i ponowoczesnościq. Wartości moralne w świadomości maturzystów $w^{22}$. Maturzyści to dla Mariańskiego ciekawi ludzie. „W wyborach moralnych znajdują się oni na duchowym rozdrożu, w warunkach dezorientacji aksjologicznej oraz demontażu tradycyjnych autorytetów"23. J. Mariański daje pogłębiony raport z badań zrealizowanych $\mathrm{w}$ pięć lat po upadku realnego socjalizmu. Nad próbami wyjaśnień i interpretacją dominuje tu - przy pełnym przyzwoleniu autora - zebrany materiał empiryczny. Dostajemy poniekąd fotografię świadomości moralnej respondentów. Mariańskiego ciekawi stosunek młodzieży do norm i autorytetów moralnych, jej cele i dążenia życiowe, także wartości prospołeczne i egoistyczne, wartości godnościowe, wartości życia małżeńskiego i rodzinnego. Stosunek maturzystów do moralnych propozycji katolicyzmu, postrzeganie religii jako instancji uzasadniającej moralność oraz preferencje obowiązków katolika pokazuje też oddzielnie (Religia i moralność w opinii maturzystów $w^{24}$. Podobnie spojrzenie tych samych maturzystów na wartości podstawowe: wolność, równość, sprawiedliwość (Priorytety wartości podstawowych w świadomości polskich maturzystów ${ }^{25}$ ). Wartości podstawowe uznawane i odczuwane pokazuje gdzie indziej: Młodzież maturalna a wartości podstawowe ${ }^{26}$. I jeszcze Patriotyzm i religia jako wartości podstawowe w świadomości polskich maturzystów ${ }^{27}$. Analizy skupia wokół tego, co można nazwać dumą z bycia Polakiem, oraz wokół obiegowego twierdzenia, że dobry Polak to katolik. Szeroko zakrojony program tych badań pozwolił także przyjrzeć się myśleniu maturzystów o rodzinie. Dało to materiał do tekstu Wartości prorodzinne młodzieży ${ }^{28}$. Przygląda się nasz autor znaczeniu, jakie młodzież przypisuje rodzinie; interesują go wartości, jakie młodzież uznaje za najważniejsze we właściwym wychowaniu młodego pokolenia, priorytety w wyborze celów ważnych w wychowaniu dzieci, także opinie maturzystów o antykoncepcji i aborcji.

Program tych badań jest szeroki, a plon obfity. Może nim autor obdzielić sporo publikacji, a i obdarować wiele osób. Jak ks. prof. St. Kowalczyka,

\footnotetext{
22 Lublin 1995.

${ }^{23}$ Tamże, s. 9.

24 „Roczniki Nauk Społecznych” 1 (1996), s. 169-188.

25 „Roczniki Nauk Społecznych” 1 (1997), s. 265-288.

26 „Studia Płockie” XXIV (1996), s. 215-237.

27 „Studia Płockie” XXV (1997), s. 175-192.

28 „Jus Matrimoniale” 2 (1997), s. 159-190.
} 
dając do zbioru studiów mu dedykowanych artykuł Orientacje moralne maturzystów ${ }^{29}$. W odrębnym tekście zbiera J. Mariański i komentuje opinie maturzystów z sześciu wspomnianych wyżej miast o pracy Kościoła (Społeczna działalność Kościoła w opinii maturzystów $w^{30}$ ). Tematyka ta wraca jeszcze w poniekąd rodzinnych dla naszego autora „Studiach Płockich”: Zadania duszpasterskie Kościoła $w$ opinii maturzystów ${ }^{31}$. Staje tu kwestia przypisywanych Kościołowi przez młodzież kompetencji w sprawach religijnych oraz w dziedzinie moralności małżeńsko-rodzinnej. Kolejny tekst prezentujący wyniki przywołanych wyżej badań w ośmiu ośrodkach miejskich to $P o-$ stawy młodzieży wobec śmierci ${ }^{32}$. Tutaj autor, po stosownym wprowadzeniu w problematykę, przygląda się częstotliwości myślenia młodych respondentów o śmierci oraz zasięgowi laickiego i religijnego jej pojmowania.

\section{Religijność i wartości}

Jeszcze cztery teksty pokazujące związek zaangażowania rytualnego młodzieży z jej preferencjami aksjologicznymi. Oto artykuł Praktyki religijne a uznawane przez młodzież autorytety moralne ${ }^{33}$. To ze znanych nam już badań maturzystów. Autor przygląda się ogólnemu stosunkowi młodzieży do autorytetów oraz uznawanym przez nią instancjom normotwórczym. Zmienną, w kontekście której deklaracje maturzystów ogląda, są ich praktyki religijne. Takie zainteresowania badawcze ks. J. Mariańskiego zachowują trwałość. Drugi z tekstów to Praktyki religijne a postawy moralne młodzie$\dot{z} y^{34}$. Intensywność praktyk koreluje tu z ogólnymi orientacjami moralnymi badanych (w tym z zasięgiem postaw zasadniczych i celowościowych), ze wskazaniami instancji decydujących o dobru i złu (Bóg, społeczeństwo czy jednostka), z siłą tendencji do relatywizmu moralnego. Trzeci z zapowiadanych artykułów ma tytuł Praktyki religijne młodzieży a uznawane wartości prorodzinne ${ }^{35}$. Interesują tu autora praktyki religijne jako zmienna niezależna różnicująca poziom aprobaty dla wartości związanych z małżeństwem i rodzina, to jest wartości prorodzinnych. Ks. J. Mariański śledzi zatem korelacje między intensywnością praktyk a uznawaniem rodziny za wartość, sza-

29 w: E. Balawajder, P. Nitecki, A. Jabłoński (red.), Ku prawdzie we wspólnocie człowieka i Boga, Sandomierz 1997, s. 224-239.

30 „Universitas Gedanensis” 15 (1996), s. 107-119.

31 „Studia Płockie” XXVI (1998), s. 183-204.

32 „Roczniki Nauk Społecznych” 1 (1998).

33 „Summarium” 24-25 (1995-1996), s. 57-72.

34 „Saeculum Christianum” 1 (1997), s. 145-171.

35 w: M. Ziemska (red.), Rodzina współczesna, Warszawa 1999, s. 124-148. 
nowaniem i kochaniem rodziców, poglądem na temat obowiązków rodziców wobec dzieci, opiniami maturzystów na temat różnych zachowań z zakresu etyki seksualnej, ich stosunkiem do osób rozwiedzionych oraz opiniami na temat stylu wychowania kultywowanego przez własnych rodziców. Wreszcie czwarty z tekstów to Praktyki religijne a postawy godnościowe młodzie$\dot{z} y^{36}$. W tym miejscu uwagę naszego autora zatrzymują takie korelaty praktyk religijnych, jak wierność własnym przekonaniom, opinie młodzieży o prywatnych sytuacjach poniżających godność człowieka, a także jej poglądy na temat naruszenia godności w stosunkach międzyludzkich i w sferze życia erotycznego.

Swoje wyniki lubi przy tym J. Mariański odnosić do wyników badań innych autorów bądź do dawniejszych badań własnych. Wkrótce się przekonamy, że to ulubiona maniera - w dobrym tego słowa znaczeniu - naszego autora. Tak jest przykładowo w artykule Kościól a religijność młodzieży ${ }^{37}$. Przynosi on relację ze wspominanych badań maturzystów, dając zarazem porównanie ze znanymi nam już wynikami badań z lat 1988/89. Ton nadaje tu pytanie o rolę Kościoła w konstytuowaniu religijności młodego pokolenia.

Zaakcentujmy w tym miejscu, że ks. J. Mariański z niekwestionowaną erudycją porusza się także po wynikach badań innych autorów. Uprzystępnia te ostatnie przy okazji prezentacji wyników własnych badań empirycznych, ale nie waha się udostępnić czytelnikom także teksty o wyłącznie przeglądowym charakterze. Jak Wartości perfekcjonistyczne w świadomości młodziezy polskiej lat siedemdziesiatych ${ }^{38}$. Wyodrębnia wartości uznawane przez młodzież szkolną i przez młodzież akademicką. Gromadzi tu, pokazuje oraz komentuje imponującą pulę badań. Podobny, przeglądowy charakter miał już obszerny materiał Młodzież polska a religia ${ }^{39}$. Idąc za W. Piwowarskim, religijność młodzieży rozpatruje na dwóch płaszczyznach: ogólnonarodowej i życia codziennego. Na tej pierwszej płaszczyźnie pokazuje jak w świetle wyników rozlicznych badań wyglądają globalne postawy młodzieży wobec wiary oraz jej praktyki religijne; odrębnie młodzieży szkół średnich, studenckiej i robotniczej. Na płaszczyźnie życia codziennego przedstawia wiedzę religijną młodego pokolenia, postawy wobec dogmatów katolickich, przekonania moralne (ogólny stosunek do zasad moralnych, postawy wobec moralności małżeńsko-rodzinnej, przekonania młodych co do związku religijności i moralności). Akcentuje główne tendencje zmian w religijności

36 „Studia Płockie” XXVI (1998), s. 163-182.

37 w: I. Borowik, W. Zdaniewicz (red.), Od Kościoła ludu do Kościoła wyboru. Religia a przemiany spoleczne w Polsce, Kraków 1996, s. 96-123.

38 „Studia Płockie” XVI-XVII (1988/1989), s. 185-237.

39 „Życie Katolickie” 7-8 (1985), s. 51-125. 
życia codziennego, a także uwarunkowania przemian religijności młodzieży - przyczyny wewnątrzkościelne oraz społeczne.

Rozróżnienie religijności ogólnonarodowej i codziennej wykorzystuje nasz badacz także dla uporządkowania pochodzącego z różnych badań, obfitego materiału empirycznego, w referacie na sympozjum katechetycznym na KUL-u 29-30 listopada 1985 roku. Sympozjum poświęcone jest Odrodzeniu duchowemu młodzieży polskiej. Stąd sporo uwagi ks. J. Mariański przeznacza na czynniki wzrostu religijności młodzieży jako ,wiary narodu" (czynniki wewnątrzkościelne, przyczyny społeczne, polityczne i gospodarcze). Wkrótce owocuje to tekstem Religijność młodzieży naszego czasu $i$ środowiska ${ }^{40}$. To, jak się okazuje, dość funkcjonalne rozróżnienie W. Piwowarskiego wraca jeszcze w artykule Religijność współczesnej młodzieży polskiej ${ }^{41}$. Jako przeglądowy, dający syntetyczną charakterystykę religijności młodego pokolenia, wypada także wskazać tekst Religijność młodzieży polskiej ${ }^{42}$. Pokazawszy współczesny kontekst przemian religijności młodzieży, autor rysuje samoocenę religijności młodego pokolenia, konstatuje zasięg i charakter jego relatywizmu religijnego, omawia praktyki religijne, aby wreszcie przejść do wniosków socjologiczno-pastoralnych. Rzecz oczywiście pożyteczna. A wszystko z wykorzystaniem solidnego materiału empirycznego. Po kilku latach J. Mariański na sympozjum w Olsztynie 13 października 2000 roku przedstawia referat utrwalony jako Religijność młodzieży polskiej wobec wyzwań reewangelizacji Europy ${ }^{43}$. Także tu, korzystając z wyników rozlicznych badań, zmierza do zarysowania syntetycznego oglądu religijnej kondycji młodych Polaków. Pokazuje ich postawy wobec religii, autodeklaracje praktyk, wierzenia. Na tle wcześniejszych publikacji nowym elementem jest prezentacja angażujących młodzież nowych ruchów religijnych w Kościele i poza nim. Niebawem pokazuje się podobna charakterem rozprawa Charakterystyka religijno-moralna współczesnej mło$d z i e \dot{z} y^{44}$. Tu także bogate, źródłowe zaplecze wyników wielu badań empirycznych; przedstawione deklaracje wiary i praktyk, wierzenia religijne oraz postawy i zachowania moralne.

40 „Seminare. Poszukiwania Naukowo-Pastoralne” (1986), s. 9-38.

41 „Collectanea Theologica” III (1988), s. 5-31.

42 „Ethos” 23 (1993), s. 97-112.

43 w: W. Nowak (red.), Młodzież a ewangelizacja w perspektywie wyzwań XXI wieku, Olsztyn 2000, s. 13-48.

44 w: St. Kulpaczyński (red.), Katecheza młodzieży, Lublin 2003, s. 15-70. 


\section{Wobec rodziny i Kościoła}

Dzięki wysiłkowi studentów KUL-u, przygotowujących prace magisterskie, udało się J. Mariańskiemu zebrać dane prezentujące myślenie młodzieży o rodzinie. Zaowocowało to książką Między sekularyzacja $i$ ewangelizacja. Wartości prorodzinne w świadomości młodzieży szkót średnich ${ }^{45}$. Badania zrealizowano w latach 1997-2000 w klasach pierwszych i ostatnich szkół średnich siedmiu miast - wielkich, średnich i małych (Jastrzębie Zdrój, Chełm, Rzeszów, Lublin, Gdańsk, Poniatowa, Ryki). Dotyczyły usytuowania młodzieży w ogólnym systemie wartości, poglądów na życie seksualne, wizji odpowiedzialnego rodzicielstwa, wierności małżeńskiej, trwałości rodziny, wreszcie spojrzenia na rodzinę pochodzenia jako wartość. Część wyników, w nader syntetycznej formie, udostępnił autor swoim czytelnikom w artykule Wartości prorodzinne w świadomości młodzieży szkolnej ${ }^{46}$. Pokazał tu rodzinę jako wartość naczelną, relacje wewnątrzrodzinne, ciągłość i zmianę w przekazie wartości codziennych, wartości związane z moralnością małżeńsko-rodzinną. W tym samym czasie ogłasza tekst Rodzina w świadomości młodzieży szkolnej ${ }^{47}$.

Sporo atrakcyjnego materiału empirycznego dostarczyły J. Mariańskiemu kierowane przezeń badania jego uczniów - i to w większości takich już bardziej zaawansowanych badawczo, to jest doktorantów - w czterech innych miastach Polski (Łomża, Ostrów Maz., Radom, Włocławek) w latach 20022005. Zasadniczą publikacją dającą w miarę całościowy przegląd wyników tych badań okazała się książka Emigracja z Kościoła. Religijność młodzieży polskiej $w$ warunkach zmian spolecznych ${ }^{48}$. Znajdujemy tu obszerne ujęcie stanu religijności młodzieży ze szkół ponadgimnazjalnych (w wieku 17-18 lat) uporządkowane według rutynowo przyjmowanych w socjologii religii parametrów religijności. Nasz autor bada wiarę, praktyki, wiedzę religijną i sposoby jej zdobywania, wierzenia religijne i parareligijne, moralność, stosunek młodzieży do Kościoła i duchowieństwa. Pokazuje stan religijności, ale także jego uwarunkowania i zróżnicowania oraz - do pewnego stopnia kierunki przemian. Nie szczędzi wysiłku, papieru i cierpliwości czytelnika. Prezentację własnych wyników jak zwykle wiąże z przedstawieniem wy-

${ }^{45}$ Lublin 2003.

${ }^{46}$ w: W. Majkowski (red.), Rodzina polska u progu Trzeciego Tysiaclecia, Warszawa 2003, s. 209-240.

47 w: B. Idzikowski, E. Narkiewicz-Niedbalec, M. Zielińska, E. Papiór (red.), Młodzież polska w nowym ładzie społecznym, Zielona Góra 2003, s. 175-189.

${ }^{48}$ Lublin 2008. 
ników innych badaczy: przywołuje, porównuje. W obfitości danych pochodzących z różnych źródeł wyniki własne o ile nie ulegają zaciemnieniu, to z pewnością przestają należeć do najsilniej eksponowanych. Pewnie trochę szkoda. J. Mariański podejmuje nawet ryzyko prezentacji swych wyników na tle wyników ogólnopolskich badań sondażowych (np. CBOS-u). Choć, co oczywiste, nie rości sobie pretensji do traktowania własnych danych za reprezentatywne.

Wyniki badań, o których mowa, trafiają też do czytelników w postaci artykułów. W nich autor eksploatuje wybrane wątki szczegółowe. Jak tutaj: Postawy moralne młodzieży szkolnej $w$ warunkach zmiany społecznej ${ }^{49}$. Pokazuje ,wybrane przejawy postaw moralnych młodzieży szkół ponadgimnazjalnych z czterech środowisk miejskich" ${ }^{50}$. Interesuje go traktowanie dekalogu jako podstawy moralności, relatywizm moralny młodzieży, stosunek do norm moralności małżeńsko-rodzinnej, postawy wobec eutanazji. Te same wątki eksponuje nasz autor także w Młodzież szkolna w Polsce wobec niektórych norm etyki katolickiej ${ }^{51}$. Pojawiają się również w księdze jubileuszowej dedykowanej przez Wydawnictwo KUL o. prof. Leonowi Dyczewskiemu: Religijność $i$ wartości moralne w świadomości młodzieży $y^{52}$. Z kolei w artykule przygotowanym do księgi jubileuszowej ofiarowanej ks. bp. Edwardowi Frankowskiemu pokazuje Postawy młodzieży szkót ponadgimnazjalnych wobec wybranych norm katolickiej etyki przedmatżeńskiej i matzeńskiej ${ }^{53}$. Stają tu postawy wobec wolnej miłości (seksu bez ograniczeń), ocena współżycia seksualnego przed ślubem kościelnym, opinie młodzieży o ślubie cywilnym i kościelnym, o zdradzie małżeńskiej, antykoncepcji, aborcji, rozwodach. Środowiska, w których J. Mariański realizuje swe projekty badawcze, a także widoczny w jego twórczości paradygmat oglądu zjawisk społecznych w ich dynamice, pozwalają naszemu badaczowi przygotować również tekst Religijność młodzieży szkolnej w matych miastach w warunkach zmiany spotecznej $j^{54}$.

\footnotetext{
49 „Przegląd Humanistyczny” 5-6 (2006), s. 39-55.

50 Tamże, s. 41.

51 „Roczniki Nauk Społecznych” 1 (2007), s. 85-118.

52 w: D. Wadowski (red.), Kultura. Media. Społeczeństwo, Lublin 2007, s. 177-190.

53 „Studia Sandomierskie” 2-4 (2007), s. 167-191.

${ }^{54}$ w: M. Zemło (red.), Małe miasta. Religie, Lublin-Supraśl 2006, s. 321-359.
} 


\section{Obszary wspólpracy}

Pytanie o dekalog jako układ odniesienia normatywnego młodzieży z Łomży, Ostrowi Maz., Radomia i Włocławka wraca jeszcze w tekście $D y$ lematy moralne młodzieży polskiej5. Wyniki własne obudowuje tu J. Mariański relacją z badań OSS „Opinia” w Warszawie (z 2003 roku) i T. Adamczyka w Lublinie (badania studentów Akademii Rolniczej z 2007 roku). Szeroko relacjonuje wyniki badań H. Świdy-Ziemby. Daje przegląd literatury światowej. Jeszcze inny wątek badań w owych czterech miastach dochodzi do głosu w artykule Rodzina w świadomości młodzieży ponadgimnazjalnej ${ }^{56}$. Nasz autor pokazuje tu dokonywaną przez młodzież ocenę domu rodzinnego, więzi i konflikty w rodzinie oraz style rodzinnego wychowania.

Organizacyjnie odmienny charakter miały badania J. Mariańskiego, które zaowocowały książką Wartości życiowe młodzieży (na przykładzie szkót pielęgniarskich) ${ }^{57}$. Rzecz została napisana wspólnie z I. Wrońską i powstała jako efekt współpracy Katedry Socjologii Moralności KUL z Katedrą Pedagogiki Wydziału Pielęgniarskiego Akademii Medycznej w Lublinie. Badania „Pielęgniarka a wartości życiowe” zrealizowano w roku szkolnym 1997/98 we wszystkich szkołach pielęgniarskich województwa lubelskiego i chełmskiego oraz częściowo tarnobrzeskiego. Dwójka autorów zbadała podstawowe orientacje moralne uczennic (pojęcie dobra i zła, stosunek do norm i autorytetów moralnych), wartości prospołeczne i egoistyczne, wartości codzienne, ostateczne i godnościowe, wreszcie wyobrażenia respondentek o wartościach i wzorach zachowań w etosie pielęgniarskim. Materiały empiryczne tych badań wykorzystał J. Mariański także przygotowując artykuł Relacje między religia i moralnościq w opinii młodzieży $y^{58}$.

Współpracując natomiast z pallotyńskim OSS „Opinia”, opracował nasz autor fragment wyników badań młodzieży warszawskiej: Młodzież wobec dogmatów wiary ${ }^{59}$. Pokazał wiarę w Boga osobowego, Trójjedynego i Stwórcę świata, wiarę w Jezusa Chrystusa, postawy młodzieży wobec dogmatów eschatologicznych. Materiał ten udostępnił też częściowo czytelnikom innej swej publikacji: Emigracja młodzieży z Kościoła? ${ }^{60}$. Ten ostatni tekst wzbo-

${ }^{55}$ w: D. Walczak-Duraj (red.), Wartości i postawy młodzieży polskiej, t. 1, Łódź 2009, s. $11-28$.

56 „Socjologia Religii” 5 (2007), s. 187-210.

${ }^{57}$ Lublin 1999.

58 „Studia Płockie” XXVII (1999), s. 99-116.

${ }^{59}$ w: W. Zdaniewicz, S. H. Zaręba (red.), Młodzież Warszawy - pokolenie pontyfikatu Jana Pawta II, Warszawa 2005, s. 27-49.

60 „Socjologia Religii” 3 (2005), s. 167-181. 
gacił wydatnie relacją z badań CBOS z lat 1996-2003 oraz wynikami badań międzynarodowych. Podobny charakter - jak w przypadku publikacji o młodzieży warszawskiej - miał wkład ks. J. Mariańskiego do książki Wartości i religia. Postawy i zachowania młodzieży tódzkiej ${ }^{61}$. W odrębnych artykułach omawia Wierzenia religijne i doświadczenie wiary ${ }^{62}$, Globalne postawy wobec religii ${ }^{63}$ oraz Praktyki religijne ${ }^{64}$.

Jak widać, ugruntował się wiodący temat zainteresowań J. Mariańskiego - religijność i moralność młodzieży. W tekście Postawy i zachowania religijno-moralne wspótczesnej mlodzieży ${ }^{65}$ autor pokazuje ,wybrane elementy postaw i zachowań religijno-moralnych, mniej lub bardziej ściśle związanych z modelem religijności katolickiej”66: autoidentyfikację religijna, praktyki, stosunek do dogmatów wiary, postawy wobec norm moralności chrześcijańskiej. Dając przegląd wyników różnych badań od schyłku lat 80., zmierza do ich syntezy i sygnalizuje kierunek przemian. W tym miejscu warto z uznaniem podnieść, a uwaga ta wykorzystuje obserwacje niżej podpisanego czynione przy okazji kontaktów z wieloma tekstami niedawnego Jubilata, że ks. Janusz Mariański z wielką - chciałoby się powiedzieć, że z programową - ostrożnością konstruuje alternatywne scenariusze zmian w świadomości religijnej młodzieży. Nie przesądza o charakterze zmian. Owe scenariusze woli traktować jako w istocie narzędzia badawcze. Zdaje się zachęcać swych następców, by we własnych badaniach przyjmowali owe scenariusze jako punkt wyjścia swej pracy i zmierzali do weryfikacji konstruowanych dzięki nim hipotez. To niezmiernie cenne w postawie badawczej autora: owo otwieranie badawczych dróg swym następcom, ale i dodawanie im odwagi. Bardzo syntetyczną charakterystykę religijności młodego pokolenia daje Mariański w Młodzież polska a religia ${ }^{67}$. Równie syntetyczny rys ma $C z y$ Kościót traci młodzież?6 ${ }^{68}$. Zwięźle zestawia tu wyniki wielu badań i porządkuje je wedle dobrze nam już znanych parametrów religijności, nadając przy tym tekstowi charakter polemiczny wobec medialnie w tym czasie nośnych tez o dystansowaniu się młodzieży wobec Kościoła i o radykalnym spadku poziomu jej religijności.

${ }^{61}$ w: S. H. Zaręba i T. Zembrzuski (red.), Wartości i religia. Postawy i zachowania młodzieży łódzkiej, Łódź 2002.

${ }^{62}$ w: S. H. Zaręba i T. Zembrzuski (red.), dz. cyt., s. 183-201.

${ }^{63}$ w: S. H. Zaręba i T. Zembrzuski (red.), dz. cyt., s. 203-215.

${ }^{64}$ w: S. H. Zaręba i T. Zembrzuski (red.), dz. cyt., s. 217-231.

65 „Przegląd Humanistyczny” 4 (2002), s. 11-25.

${ }^{66}$ Tamże, s. 11.

67 „Keryks” 1 (2002), s. 125-140.

68 „Pastores” 1 (2004), s. 125-135. 


\section{Ciężary warsztatu}

Daje się zauważyć w badaniach J. Mariańskiego, że jego respondenci nie zawsze są zorientowani, co tak naprawdę badacza interesuje. Stąd - rutynowo proszeni o ocenę ankiet - nie stronią od zarzutów, że zbyt wiele w nich religii, Kościoła, „ingerencji księży”. My rozumiemy, że pewne przeakcentowanie wątków religijnych uzasadnione jest programem badań. Już inaczej, a to z większym zrozumieniem dla respondentów, wypada skomentować ich zarzuty o innym charakterze. Zarzuty - dodajmy - wcale częste. Oto w przypadku niektórych ankiet opinie negatywne bywały prawie tak częste, jak pozytywne. Krytyka dotyczyła stylu ankiet. Zwracano uwagę, że są ciężkie, niejasne, pisane trudnym językiem. Autor niniejszego jest skłonny to potwierdzić. Nie zawsze widać wysiłek przełożenia języka badacza na język respondenta, zdarza się swego rodzaju powtarzanie pytań, razi nadmiar pytań zamkniętych.

To jednak, wobec czego wypada szkicującemu to sprawozdanie nieco się zdystansować, to niedostatki tego, co chciałoby się tu nazwać czystością formalną. J. Mariański nie waha się - a z pewnością robi to świadomie - łączyć wątki o różnej proweniencji i różnorakim charakterze. Oto relacjonując wyniki badań własnych, zwykle dając syntezę dociekań badawczych swych uczniów, wprowadza ponadto informacje o wynikach badań innych badaczy (autorów badań monograficznych), niekiedy dorzuca informacje o wynikach ogólnopolskich badań sondażowych CBOS-u, a wreszcie ustalenia socjologów zachodnich. Bywa, że zderza się to wszystko w jednym podrozdziale bądź punkcie artykułu. Nawet na jednej stronie. Co więcej, informacje o wynikach badań współwystępują z wątkami ideowymi zaczerpniętymi z nauczania Kościoła, choćby z enuncjacji papieskich czy Katechizmu Kościoła katolickiego. J. Mariański najwyraźniej szuka w nich inspiracji do badań bądź pomocy w interpretacji ich wyników. W efekcie powstaje czasem tekst-worek, do którego napchano zbyt wiele i nazbyt przypadkowo. Moim studentom mówię: czytajcie ks. prof. Janusza Mariańskiego, ale go nie we wszystkim naśladujcie. Słyszę zatem pytanie: to po co czytać? Tak, czytać warto. To wręcz konieczne. Poznaje się wyniki wielu badań polskich i obcych, dostaje się informacje o sytuacji w innych - zwłaszcza zachodnich krajach, zyskuje się kontakt z efektami poszukiwań nowszych inspiracji teoretycznych. A to szczególnie dzięki obszernym wstępom w publikacjach, zwłaszcza książkowych, J. Mariańskiego przeznaczonych na prezentację zaplecza teoretycznego własnych badań empirycznych. 


\section{W stronę zakończenia}

Już Irena Nowakowa, pisząc wstęp do książki o młodzieży płockiej, zatem do jednej z wcześniejszych publikacji naszego autora, i komplementując pracę J. Mariańskiego, podkreślała: „Te cechy książki nadają jej walor poznawczy o charakterze niemalże podręcznikowym w zakresie podjętego przez autora tematu" ${ }^{\prime 9}$. Trudno tej opinii zaprzeczyć. Co więcej, ów podręcznikowy charakter publikacji J. Mariańskiego z biegiem lat coraz bardziej się uwyraźniał. Dlatego ks. Janusz Mariański jest dla nas tak bardzo ważny. I tak bardzo potrzebny.

Był i jest nadal ważny i potrzebny nie tylko dla profesjonalistów - badaczy polskiej młodzieży. Także dla znacznie szerszej publiczności: czytelników prasy. Przemawiaja za tym wywiady udzielane przez ks. prof. J. Mariańskiego. W ten sposób mówił on o sprawach młodzieży na łamach chronologicznie ujmując - „Za i Przeciw”, „Zorzy”, „Kuriera Lubelskiego”, „Powołania. Pisma Alumnów WSD w Sandomierzu”, „Wiadomości KAI”.

Zarysowane tu kierunki zainteresowań i naszkicowane elementy organizacyjne warsztatu ks. Janusza Mariańskiego żadną miarą nie wyczerpują tego, co o nim jako badaczu młodzieży powiedzieć wypada. Obszarem refleksji należałoby uczynić także samą młodzież, której wizerunek od ponad 30 lat autor nam odsłania. Ale to szczęśliwie już podjęto. Efektem są zwłaszcza prace D. Walczak-Duraj, J. Kopki i J. Gajosa niedawno udostępnione czytelniczej publiczności w księdze jubileuszowej ku czci Księdza Profesora przygotowanej pod redakcją J. Baniaka Między socjologiq i teologiq. Pola zainteresowań i badań naukowych Janusza Mariańskiego ${ }^{70}$. O ks. J. Mariańskim jako badaczu młodzieży pisano również w pracach magisterskich (A. Marciniec w Instytucie Socjologii WSP w Rzeszowie, dalsi magistranci przy okazji relacjonowania innych tematów). L. Gajos już dał na łamach „Teologii Praktycznej” i „Universitas Gedanensis” studium na temat badań Mariańskiego nad młodzieżą. Książki Jubilata cieszyły się i cieszą u recenzentów sporym wzięciem.

Dorobek ks. prof. Janusza Mariańskiego dotyczący młodzieży jest solidny. By nie powiedzieć: imponujący. Chciałoby się rzec: wystarczy. Jednak wiemy, że to dalece nie wszystko. Bo polska młodzież, choć tak w badaniach J. Mariańskiego ważna, przecież nie wyczerpuje ani jego zainteresowań ani jego pisarskiego dorobku.

${ }^{69}$ I. Nowakowa, Wstęp, w: J. Mariański, Postawy społeczno-moralne młodzieży płockiej (studium socjologiczne), Płock 1984, s. 7.

${ }^{70}$ Poznań 2010. 


\section{Polish Youngsters as the Area of Research of Father Professor Janusz Mariański (Summary)}

This article is an attempt to systematize the academic research of Fr. Prof. Janusz Mariański, the Chair of the Sociology of Morals at the Department of Sociology of the Catholic University of Lublin (Katedra Socjologii Moralności na Wydziale Socjologii Katolickiego Uniwersytetu Lubelskiego), dedicated to the situation of youngsters in Poland. According to Prof. Mariański, the research area that is especially privileged today, apart from the sociology of religion and the sociology of morals, is the sociology of young people. He is interested in the system of values of the young generation, especially in the context of multi-directional changes that are taking place in the modern Polish society. The centre of Prof. Mariański's academic interests is the moral, religious and social stance of the young people in Poland. He presents their attitudes and viewpoints within numerous conditionings and relationships, while taking into account the works of different sociologists on the subject. 